\title{
Ensuring of the enterprise operation effacacy: management aspect
}

\author{
Tetyana Stupnytska $^{1}$, Olga Kalaman $^{2}$, Tetyana Markova ${ }^{1}$ \\ ${ }^{1}$ Department of Accounting and Auditing, Odessa National Academy of Food Technologies, Odessa, Ukraine \\ ${ }^{2}$ Department of Management and Logistic, Odessa National Academy of Food Technologies, Odessa, Ukraine
}

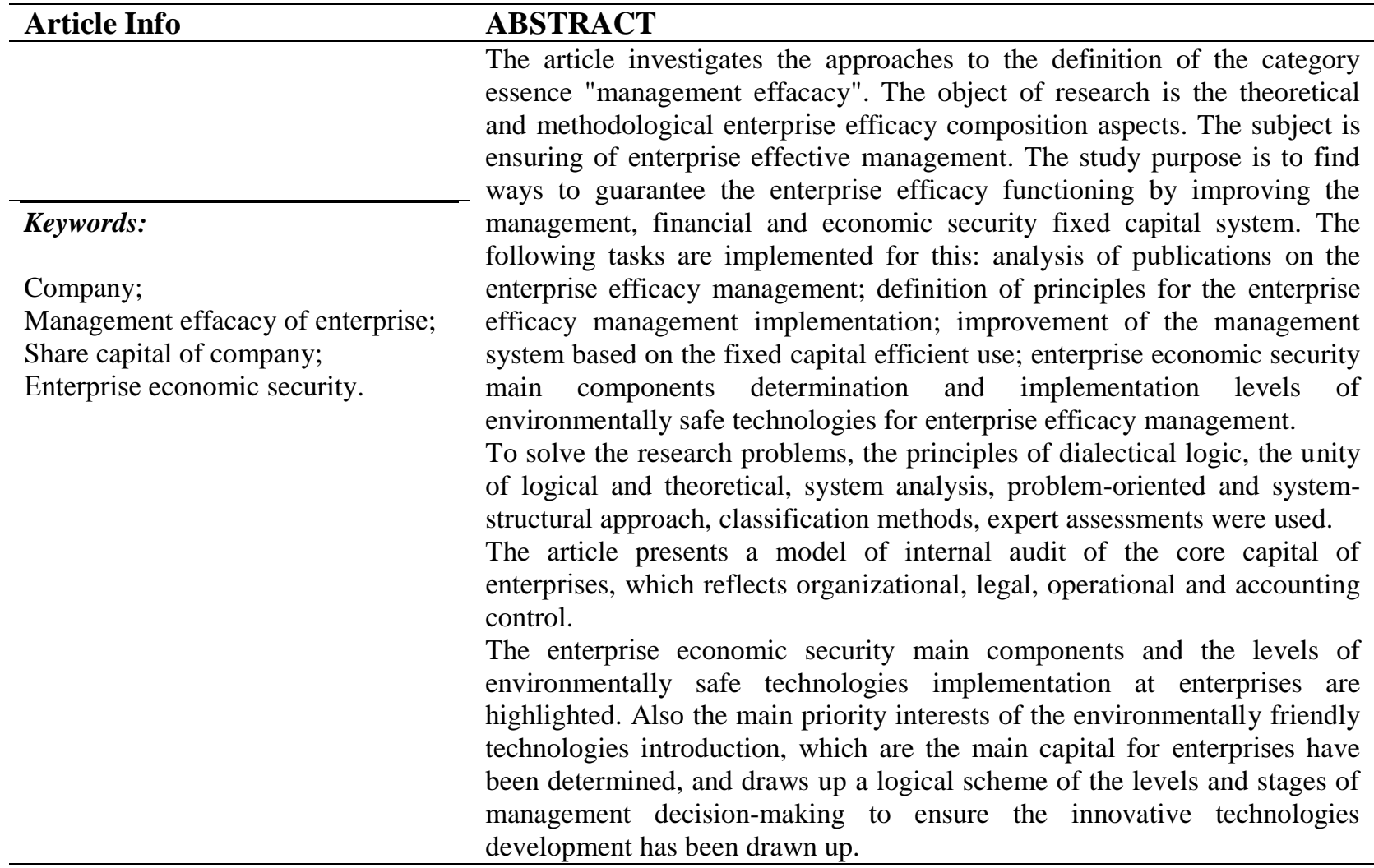

Corresponding Author

Olga Kalaman

Odessa National Academy of Food Technologies, (Odessa),

ONAFT, 112, Kanatna Street, Odessa, Ukraine, 65039.

e-mail: kalaman.olga@gmail.com

\section{Introduction}

Ensuring performance is one of any modern enterprise main tasks. In the conditions of tough competition and the negative influence of other external and internal factors, this task is rather difficult to accomplish. That is why, at the end of the last century, a special section emerged in management science - performance management, which should provide business with the necessary methodology and tools to maintain a steady increase in the effacacy of its activities.

Effective enterprise economic activity, its financial stability, solvency and investment attractiveness are directly dependent on properly planned investment in its assets. One of the significant components of the enterprise assets is its non-current assets, i.e. share capital of the enterprise. Since the fixed capital is involved in all types of enterprise activity, the process of managing the activity through its use is a complex of interrelated functions of managing the main capital, which are carried out in a certain sequence and are aimed at improving its use effacacy and solving specific problems. 
To date, the pressing enterprise management issue is also ensuring its financial and economic security. Aspects of this problem has been investigated by us over a long period, and the such research results were reflected in previous publications, but they require constant research due to changes in the functioning of the enterprise in modern conditions.

Determining the parameters and indicators of management effacacy as a whole and, accordingly, the effacacy of the enterprise's functioning is a multidimensional process and little described in modern literature. Scientists like A. G. Goncharuk [13], A. A. Vaschenko [38], N. V. Chebanova, L. E. Revutskaya, N. M. Koroleva [7], N. S. Medzhybovskaya [22], S. V. Onyshko [24], O. V. Boyko, O. E. Kateriniuk [6], O. M. Tarkaniya [36], L. P. Kulakovska [19], O. I. Zakharov [40] and others devoted their works to the issue of investigating of management effacacy. P. Drucker in his work "The Effective Executive" pays attention to the concept of "effacacy", which is first defined as the correct target guideline for an enterprise, then it is attempted to be achieved using the minimum amount of resources (to ensure effacacy) [12]. Kinds of effacacy also play a special role in the studies of many modern scientists, in particular, Alaoui A. M. highlighted the Xineffacacy situation when the costs incurred by the company exceed the costs which are minimally necessary to maintain output at the current level [2]. Such scientists as J. Van Horn [37], R. Coase [9], J. S. Nelson[21], J. K. Shim, J. G. Siegel[32] et al[18]. In its turn, the enterprise economic security aspects, which is an efficacy enterprise management integral part, were studied by Didier van Caillie [11], A. Ianioglo, T. Polajeva[16], R. Vascones[27], Y.G. Chernysheva, G.I. Shepelenko[8], W. Jeanne[17], G. Mintzberg [23], M. Porter, E. Michael [28] and others. However, questions directly related to ensuring the enterprise efficacy functioning by means of perfection of management core capital and the financial and economic security, are still poorly understood. This fact determined the choice of the subject of the article.

\section{Materials and Methods}

The relevance of these questions influenced the choice of the research topic, its goals and methods. Thus, the purpose of the study is to find ways to provide the enterprise effective functioning by improving the fixed capital management system, financial and economic security.

For achievement this purpose, the following tasks were implemented:

- analysis of scientific publications on the enterprise efficacy management,

- definition of the implementation enterprise efficacy management main principles;

- enterprise management system improvement based on the effective use of fixed capital;

- determination of the main components of the enterprise economy security and the implementation levels of environmentally friendly technologies to ensure enterprise efficacy management.

To solve the research problems, the principles of dialectical logic, the unity of logical and theoretical, system analysis, the problem-target approach, classification methods, and expert assessments were used. The problem-target approach, expert assessments, system analysis are applied while improving the effacacy of using fixed capital on the basis of improving the system of managing the enterprise economic activity based on changing the content of functions of managing the use of fixed capital. The system-structural approach allowed to generalize the conceptual and theoretical foundations of a levels scheme logical formation and the making management decisions stage to ensure the development of innovative technologies, identify four levels of priority interests, on the introduction of environmentally sound technologies at enterprises for effective management and development, as well as identify the economic security enterprises main components.

\section{Theory}

Enterprise efficacy management is an integrated management approach that combines various activities of an enterprise, including strategy, personnel and operational management, planning, analysis, accounting and control, appropriate methods, models, systems and software to ensure a steady increase in the enterprise efficacy. It is integrated into all organization management aspects and also decision-making processes so as to realize a focus on achieving the best results.

To successfully use the methods and tools of performance management in the activities of modern enterprises, an appropriate organizational and economic mechanism is needed, acting as a system of interrelated elements, including methods, organizational structures, operations, information technology tools, tools and tools that interact with each other and perform a cyclical set of strategic and operational tasks and functions for 
measuring and evaluating the effectiveness, the production of managerial actions and monitoring of their performance, ensuring sustainable growth performance of the company. Such a mechanism should take into account the activities specifics of a particular type of economic activity. The authors have proposed to improve the economic activities management system based on the fixed capital effective use, builded on the most rational management functions: analysis, motivation, management policy, control. To improve the fixed capital use efficacy, research has shown that internal control over its movement and use is necessary, the function of which can be performed by the internal audit service. The enterprise economic security main components and the implementation levels of environmentally friendly technologies at enterprises have been highlighted.

The modern understanding of effacacy includes a complex of economic, natural, social, political and scientific and technical conditions for the productive forces and production relations functioning. On this basis, it can express the effectiveness of the functioning of the labor force, means and objects of labor within the national economy, industries, regions, enterprises, their divisions and individual processes. Thus, as a result of its genesis, the concept of "effacacy" has gained significant development, expanded, went far beyond the bounds of economics, was widely adopted and applied to any type of activity.

It can be noted that the effectiveness of an object or process (production, enterprise, economy) is usually associated with its goal and is understood as the effectiveness, completeness of achieving the goal, the ratio of the result obtained and the costs. Descending from the classical school, this understanding of effacacy is firmly established in economic theory. At the same time, since the enterprise can have many goals, and they can be of a different nature, then effacacy is a multi-valued and differentiated concept. In economics, there are dozens of types of effacacy, the most common of which include the following: financial, social, socioeconomic, environmental, structural effacacy of individual industries and regions, absolute and relative, relative effectiveness of investments, effacacy of individual business entities, effacacy of a unit, effacacy of a process, employee effacacy, etc. [13].

So, Deyneka O. G., Russov K. A., Mikhalko A. V. noted that in order for the organization to function, it must be managed [10]. According to A. Vashchenko [37], the production efficacy and economic activities should be characterized as the end result of the resources use in the various goods and services production. The management activity type, features of the functions performed, associated with different levels of management activity in the economic system, according to the results of research by the scientists [7] are the main objective factors influencing the managers information needs formation. Medzhibovskaya N. S. believes that effective management in modern complex conditions of enterprises and aggravating of competition requires the modern management concepts use, fast answer to a changing situation, it is impossible without accurate and comprehensive information about the production and financial activities stateand enterprise resources, established business processes and executive management [22]. The functioning of any system is determined by the state of the control system as a specific set of related means, methods, subsystems that provide the control process. At the same time, it is important to take into account the existence of various ways of measuring the results of activities, which, in its turn, forms differences in the approaches to evaluating management effectiveness. If the target concept of effacacy presumes that an organization should achieve certain goals in its activities, and effacacy characterizes the degree of achievement of the goals set, then within the system concept, management effacacy describes the degree of adaptation to the internal and external organization environment [24]. Effective and objective impact and operational control over the state of the entire enterprise (business) should be implemented on the basis of common management criteria, which are usually integral indicators. However, in accordance with the modern cost approach to business valuation, which is becoming more common in management practice, the main criterion of management should be the company's value [31]. Boyko O. V. and Kateriniuk O. Ye. note that enterprises that react to minor changes in organizational management structures that were caused by market requirements, are trying to adapt the existing management structure to changes, that is, to organize activities in a crisis, high risk, instability of the internal and external environment, or create a so-called transitional structure [6]. Boyarko I. M. and Samusevich Ya. V. highlight value-oriented management, which is a holistic process aimed at increasing the value of an enterprise for owners and shareholders and increasing its market value by unlocking the potential of competitive advantages associated with tangible and intangible assets [5]. Thus, in the economic literature there is no single approach to determining the effectiveness of management, which requires further study of this problem.

\section{Results and Discussion}


There is a systematic, in our opinion, essence definition of efficacy management: efficacy management is a continuous, refine results through systematic approach scientifically based decisions, continuous organizational learning, and emphasis on performance reporting [1]. It is the most comprehensive and defines efficacy management as a special management approach. But since effacacy is the most important characteristic of the activities of any enterprise, taking into account the above-mentioned, it is advisable to take the following definition of this concept as a basis.

Enterprise efficacy management is an integrated management approach that combines various activities of an enterprise, including strategy, personnel and operational management, planning, analysis, accounting and control, appropriate methods, models, systems and software to ensure a steady increase in the enterprise efficacy [20].

To the basic principles of the implementation of the enterprise efficacy management we assign the following:

1) measuring the performance of the enterprise and its individual divisions, provides for the development of performance indicators and setting goals for improving effacacy;

2) assessment of the effectiveness of the enterprise, provides for the determination of the actual effacacy of the enterprise, its comparison with the goals of effacacy and identification of reserves for its growth;

3 ) the implementation of management actions, providing for the adoption of decisions that contribute to improving performance, that is, for each of the identified reserves, solutions are developed to approximate the actual value of the indicator with the target one;

4) performance monitoring, provides for monitoring the implementation of decisions and collecting information necessary for further measurement of the effectiveness of the enterprise.

Effective enterprise economic activity, its financial stability, solvency and investment attractiveness is directly dependent on properly planned investment of funds in its assets.

One of the significant enterprise assets components is its non-current assets, i.e. funding at the enterprise main capital. Since the fixed capital is involved in all types of enterprise activity, the process of managing the activity through its use is a complex of managing the main capital interrelated functions, which are carried out in a certain sequence and are aimed at improving the its use efficacy and solving specific problems.

Since fixed assets are involved in all types of enterprise activity, the process of managing activities through its use is a complex of interrelated functions of managing capital assets, which are carried out in a certain sequence and are aimed at improving the its use efficacy and solving specific problems.

Studies of the composition, structure, dynamics, and use of both the entire fixed capital of enterprises and its elements have shown that its performance indicators are not stable, the basic operating facilities have a fairly high degree of wear. Sources of financing for fixed capital are mainly represented by their own sources. The lack of borrowed sources of financing of borrowed capital is due to the low level of lending to Ukrainian enterprises and rather high interest rates for long-term loans, on the one hand, caused by high credit risk and the desire of enterprises to reduce it by improving the capital structure on the other hand, presence of faults legislative mechanism of recognition of the company bankrupt.

Therefore, to ensure the stable operation of enterprises and to attract sources of financing of fixed capital, it is necessary to improve the management of their business activities. Studies have shown that the system of enterprise economic activities management by improving the fixed capital use efficacy, is advisable to improve by changing the content of certain management functions, as the management activity involves the implementation of certain functions, each of which is aimed at solving specific and complex problems posed by the enterprise in its activities. In modern management theory there are differences in the positions of various specialists in the definition of these functions, their differentiation and classification. The analysis of these positions revealed the most common management functions: planning, organization, coordination, motivation and control. The conducted research, as well as analysis of the fixed capital of enterprises, allowed us to identify the following functions of managing the use of fixed capital: analysis, motivation, management policy and control. The first function of management, the economic analysis, involves a comprehensive study of the state and use of both the entire fixed capital and its elements. An innovative approach to the analysis of fixed capital is, in our opinion, an in-depth analysis of factors covering all activities and influencing the change in return on capital, with the determination of their value [33].

The next management function, motivation, covers the strategic goals and objectives of asset management: based on the mentality of managers and owners of the enterprise, as well as the results of the analysis of fixed capital. The capital management policy (the third management function) includes, in our opinion, three components: 
- the policy of managing the profitability of fixed capital: eliminating the influence of negative and increasing influence of positive factors, revealed as a result of its economic analysis, on changes in the profitability of fixed capital;

- depreciation policy - a set of measures aimed at attracting its own additional sources of financing of fixed capital to achieve the goals of updating operating fixed capital;

- investment policy - aimed at assessing the investment attractiveness of an enterprise with the aim of attracting additional sources of financing of fixed capital and choosing the optimal direction for investing free funds with a long-term goal (capital, long-term financial investments, long-term investments in the capital of other enterprises).

The fourth function of managing the use of fixed capital is control, which includes the operational management of elements of fixed capital and monitoring the its use efficacy on the basis of goals and objectives set, and fixed capital management policy. In our opinion, for the efficacy fixed capital use and the fulfillment of the listed management functions, the company needs to create an internal audit service, whose activities will increase the efficacy of fixed capital use and, accordingly, have a positive effect on all activities of the enterprise.

All of the above-mentioned allowed us to offer an improved system of business management by improving the effacacy of fixed capital use, presented in Fig.1 [33].

One of the functions involved in the management of the enterprise's business by increasing the efficacy of fixed capital use is internal control. According to the methods of organization of internal control, it includes: audit, thematic audit, internal investigation and internal audit.

The goal of internal audit is to improve the effacacy of personnel functions in order to improve the enterprise performance [19]. Internal auditors are highly qualified specialists who have not only economic and legal professional training, but also know the specifics of the production process technology and product marketing at the enterprise, and also have practical skills in taxing the enterprise's activities and drawing up its tax and financial statements. Therefore, in our opinion, it is internal auditors who can make an independent expert assessment of the managing fixed capital efficacy.

Depending on the specifics of an enterprise, internal audit can be represented both by one employee and the whole service (internal audit department), whose functions are fixed in the "Regulations on the department of internal audit" and its place in the enterprise activity management system is determined.

In accordance with the improved business management system by increasing the fixed capital efficacy use internal control function is entrusted in full to the internal audit service. The model of internal audit of fixed assets of enterprises reflects organizational, legal, operational and financial control. Thus, organizational control provides control over the concentration and performance of functions of managing the elements of fixed capital in business units, as well as monitoring the availability of sources of information on machine and paper carriers for managing fixed capital. Legal control is exercised by monitoring compliance of the fixed capital management policy with laws and regulations, as well as monitoring compliance with the form and content of documents containing information on fixed capital, regulatory and legislative acts.

Operational control is reflected in the control over the composition, structure, movement and use of fixed capital elements and fixed capital in general, covering all activities, as well as in controlling the influence of factors on changes in the profitability of fixed capital. Accounting financial control is carried out by controlling the composition, structure, movement and use of fixed capital elements and fixed capital in general, covering all activities, as well as by controlling the influence of factors on changes in the profitability of fixed capital. An industrial enterprise can be considered as an integrated farm engaged in multidimensional activities with the main goal of making a profit by supplying products to the market and providing the services indicated in the charter. The organizational, economic, production and technical tasks of such an enterprise are determined by the cohesion thanks to the activities of a certain governing structure, the functioning of a single organizational and technical base, and the availability of operational and economic independence. Structural units of the enterprise (workshop, site, brigade) differ in the form of the production process, depending on the type and enterprise size. 


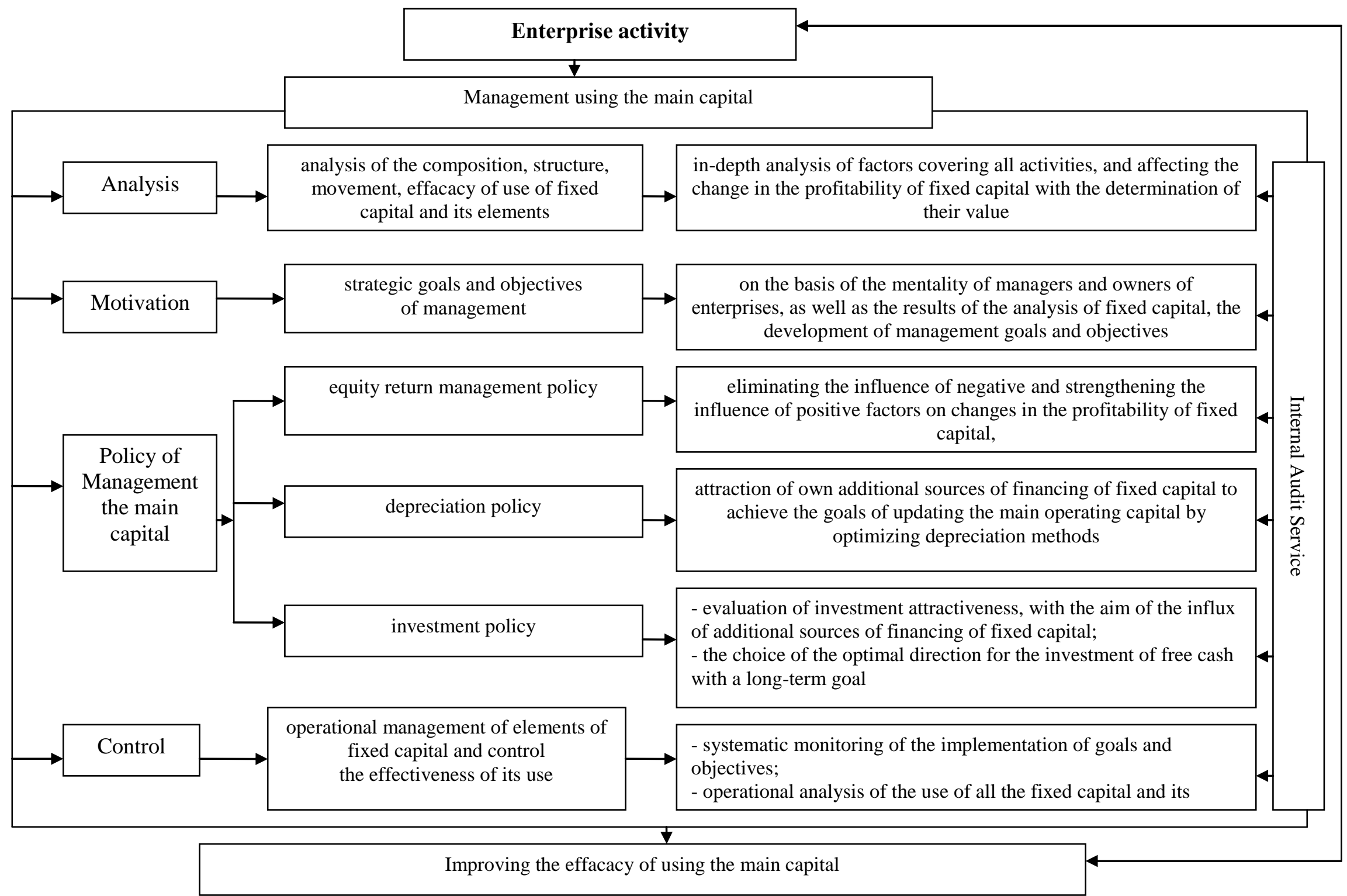

Figure 1. Business management system, improved by raising the fixed capital use efficacy 
The enterprise development level is characterized by such indicators as organizational and technical activity in cooperation, specialization, combination of production, introduction of innovations, improvement of technologies and organization of production, ensuring efficient operation of economic services $[3,35]$.

It should be noted that one of the most important conditions for the normal functioning of fixed capital and the development of business in the economy of any country is the enterprise economic security. In order to achieve the economic security highest level, an enterprise should work to provide maximum safety of main components its work functional. The enterprise economic security functional components are a combination of the main areas of economic security that differ significantly from each other in their content. The analysis of literary sources allows to identify the following enterprise economic security components (Fig.2).

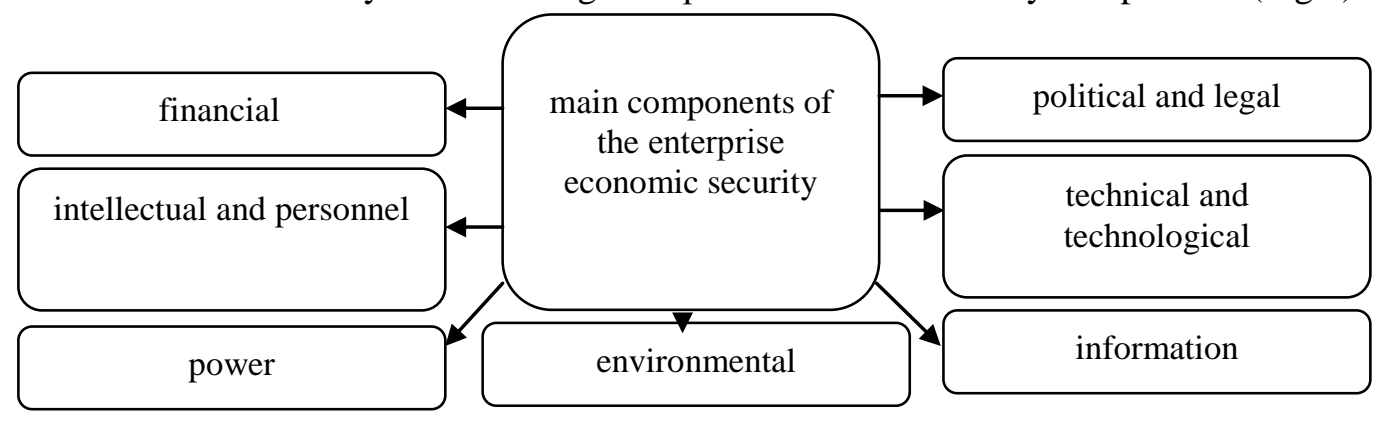

Figure 2. The enterprise economic security main components

1. The financial component is aimed at achieving the most efficient corporate resources use. It is considered crucial for the effective functioning of the entire enterprise. An objective prerequisite for effective cash flow management, according to A.M. Podderyogin and Ya.I. Nevmerzhitsky, is their structuring - the formation of an ordered set of cash flows in accordance with established criteria (or groups of criteria) and determining their basic functional and organizational features. Cash flow structuring helps to level the impact of the features of individual cash flows on their management process by identifying a management object based on a targeted sample of cash flows, as well as to simplify and reduce the information amount base for making financial management decisions $[4,26]$.

2. The intellectual and personnel component provides for the preservation and development of the enterprise potential and efficacy personnel management. According to O. M. Tarkaniy [36], the formation of whole efficacy enterprise management system should also take into account the human factor. In this aspect, the main task of organizing the work of the management system is to enable the employee to achieve a certain personal goal, directing his own efforts to achieve the goals of the enterprise.

3. Technical and technological component - the degree of compliance of the technologies used at the enterprise with the best world analogues in optimizing resource costs. According to EA Plakhotnik, the use of progressive technology, modern and timely updating of the means of labor, ensuring the flexibility of production, proportionality, parallelism, continuity, rhythm of processes and the sustainability of the enterprise, makes it possible to produce competitive products and ensure its normal level of profitability. The use of high-performance equipment and advanced technology contributes to increasing capital productivity, reducing the labor intensity of technological processes, and increasing labor productivity $[25,30]$.

4. The political and legal component covers a comprehensive legal framework for the activities of the enterprise and compliance with current legislation.

5. The economic security information component is an effective information and analytical support for the enterprise economic activity with the help of modern accounting and analytical software products and information technologies. The information technology market has been developing dynamically over the past few years, according to expert estimates, its growth exceeds $10 \%$ per year. At the same time, the information security sector is developing at even greater rates - by more than $25 \%$ per year. All of this can be explained by two factors: management's attention to information security has increased, and the lack of information security in modern information technologies has increased [29]. The introduction of modern information technologies is usually associated with significant investments and, accordingly, with the need to justify the effectiveness of these investments. On the other hand, in order to plan a budget on the basis of real business indicators, you need to clearly understand the items of expenditure and the factors that shape them. This problem is particularly acute with the integration of these systems, when it is necessary to manage the infrastructure of several areas of enterprise activity. 
6. The power component of economic security is to ensure the physical safety of employees of the enterprise and preserve its property.

7. Environmental component - compliance with current environmental standards to minimize costs from environmental pollution. In our opinion, minimization of costs from environmental pollution is achieved by an enterprise investing in equipment (fixed capital) of an energy efficient operation, including alternative energy (especially for solving heat supply issues).

Thus, the study of the priority interests of the introduction of environmentally friendly technologies at enterprises gave us the opportunity to distinguish four levels [14].

At the first level, this is the international community, the goal of which is introducing energy-saving technologies (fixed assets), and reducing environmental damage caused by thermal pollution by "greenhouse gases", that is, to improve the state of natural balance and ensure life safety. Environmental damage and its consequences can also manifest themselves in a wide variety of types and sectors: deterioration of human health due to the consumption of polluted water and air pollution, reduction of agricultural yields in industrial areas polluted by emissions, reduction of equipment service life due to metal corrosion.

The second level is the interests of each individual country, whose goal is the sustainable development of its economy. Considering that the state's economic security depends on energy and environmental security, the development and implementation of scientifically advanced and environmentally friendly technologies is one of the government's priority tasks. In addition, to solve these problems, the of European Union and other developed world countries have chosen the "clean production" policy. The second level is characterized by two signs for the introduction of innovative and technological energy-saving equipment:

1) reducing emissions, ensuring environmental safety of life and reducing the level of harm to human health;

2) achieving energy security on the basis of energy savings in the areas of production and energy consumption, more fully attracting non-traditional energy sources in order to save fossil fuels and guarantee full satisfaction of energy needs.

The third level is the level of the manufacturer of energy-saving equipment, the priority interests of which is to maximize profits, profitability and prices. This is the level of market relations, namely the provision of proposals for innovative technological equipment.

Market demand is provided by the fourth level - the level of users of this equipment. The priority interests of users are the minimum price (cost) for innovative technological equipment and, when implemented, getting a quality heat supply service with reduced costs compared to traditional heating. The only exceptions are enterprises that are included in the register of pollutants of natural objects and which pay for environmental pollution. However, this fee does not encourage manufacturers to reduce the anthropogenic load, since the standards for fees, for example, for atmospheric pollution, are lower than the costs of weatherproof equipment. Thus, the state should use such mechanisms, business entities were encouraged to introduce environmentally friendly energy supply technologies.

The economic and environmental interests of all participants in the production process and the use of innovative technological equipment of an energy-saving nature necessitates the creation of a mechanism to promote the development of alternative energy in the interaction of three main factors, from our point of view, namely technical and technological, economic and environmental. Achieving a high level of interaction of these factors will ensure energy and environmental security, which are the economic security links, that is, our country strategic task for the coming years is to accelerate the integration process in a developed world countries number.

According to technical and technological factor, the contradictions between the two categories of subjects in the market of innovative and energy-saving equipment, namely, manufacturers and users of this technology, remain relevant. In our opinion, these contradictions can be resolved by improving the regulatory, methodological and legal framework of the legislation, state support for customers of innovative technological equipment on the use of non-traditional renewable energy sources, viewing the pricing of a unit of heat and power products produced by modernized energy-saving and environmentally friendly technologies in thermal power plants and boilers, improving environmental accounting and control in the framework of the commitments of the Kyoto agreement.

As a result of our study, nine main approaches have been identified that create the basis for the formation of mechanisms for the ecological and economic effacacy of developing innovative energy-saving technologies (fixed assets) [15]: systematic, integrated, legal, management, mobility to modern requirements, process, integrated, innovative, economic and environmental. 
Among the most appropriate methods of conducting such research is system analysis, which can be applied to solve problems in any sphere of society. In addition to the systematic approach, they also distinguish the management one. The choice of a particular approach is reflected in the difference between the procedures for regulating management activities. Thus, the "systemic" approach predetermines the need for a systemic representation of the object of management, and the "management" approach predetermines a systemic representation of the implementation of management activities and consequently, will be expressed in various requirements for special methods, tools and tools for analyzing and developing mechanisms of public administration [34, 39]. Also economic security policy should be based on a systems approach and it should be diversified and meet modern organizational, technical and technological conditions. In developing the economic security policy, the system approach can, from our point of view, be detailed in stages: the definition of an array of information (managerial, banking, trading, personnel and other information that is of great value to the enterprise itself and can be used to ensure a competitive state in conducting modern conditions and managing business); classification of objects and resources of the enterprise; predicting of a set of potentially dangerous economic threats; carrying out the primary audit of the enterprise's economic security system with identification and assessment of potential risks; selection of optimal management solutions for eliminating economic threats and balancing the enterprise economic security system. Having considered the enterprise economic security main components, one cannot but say about the close the state and the enterprise economic security relationship.

The products competitiveness, the level of capacity utilization and resources, financial and executive discipline, and well-thought-out pricing policies depend on the specific enterprises state. The state economic security is derived from enterprise economic security ensuring. The structural competitiveness units determines national economic security, contributing to the state prestige in the world market. But, the state economic security is the base that determines the security of individual production units [34]. The state has the greatest influence on the enterprise economic security formation. Using direct and indirect intervention methods, it regulates the economic and social country development. The enterprise interests and the state do not always coincide. Their common measure is economic security.

The implementation of the concept of strategic management of economic security is possible under the condition of a strategically oriented organization, when a strategic planning system is used, it allows developing and implementing a system of strategic plans, carrying out ongoing activities, aiming at achieving the set strategic goals.

The implementing effective enterprise management process includes: actions to use modern technologies to ensure effective management (technical means of protecting information systems, wealth and personnel); efforts to establish and maintain close cooperation with government authorities in the prevention of economic crimes and economic security; timely and adequate protective measures against the actions of competitors and criminal groups; constant collection and analysis of information about the processes occurring in the external and internal environment of the enterprise; timely detection of new threats and development of measures to neutralize them or reduce the level of impact; determining the place and role of all structural units of the enterprise in its economic security system; constant informing and briefing of managers and personnel and personnel on security issues; a system for the selection and training of employees of the enterprise economic security service [38].

Since many enterprises, which are the most important structural element of the national economy, turn out to be unprofitable, they should pay special attention to the problems of risk management and ensuring their own economic security, which is to achieve stability and maximum effacacy of their functioning, as well as high future development potential.

\section{Conclusions}

Thus, the article examines the approaches to the definition of the category "management effacacy" essence in the scientific economic literature, and, as the research has shown, this concept is becoming more widespread and recognized. On the basis of systematization and generalization of interpretations of many scientists, it has been determined that the effacacy of enterprise management is a direction in science in the context of the subject of "management", which is based on the principles of accounting and analytical support, covers the economic tools (economic methods and techniques) of developing and ensuring the business development objectives implementation, also achieving goodwill growth. The basic implementation principles of enterprise 
performance management have been defined. Also, the economic activity management system improvement the basis on fixed capital effective use, based on the most rational management functions: analysis, motivation, management policy, control has been proposed. To improve the fixed capital use effacacy, as research has shown, internal control over its movement and use is necessary. The function of internal control, in our opinion, can be performed by the internal audit service, which is proposed to be organized in modern enterprises. A model of internal audit of the core capital of modern enterprises has been developed, which reflects organizational, legal, operational and accounting financial control.

In the process of researching the management of the effacacy of the enterprise, the results were obtained, which allow to draw the subsequent derivations.

1. In the genesis process and evolution, the concept of "effacacy" has gone far beyond the scope of economics and, taking into account the diversity and complexity of this category, it must be considered as a complex concept that includes a number of species, the relationship and combination of which determine its essence. The study of publications of scientists has allowed to establish that the effacacy of an enterprise is defined as an economic category, expressing the ability of an enterprise to achieve established tactical and strategic goals with optimal expenditure of resources and most fully ensures the realization of the economic interests of its owners.

2. Analyzing the methodology of enterprise performance management, this concept is defined as an integrated management approach that combines various activities of an enterprise, including strategy, personnel management, operational management, planning, analysis, accounting and control, relevant methods, models, systems and software for ensuring sustainable growth of enterprise effacacy. The principles of the implementation of enterprise performance management have been formulated.

3. In accordance with the improved business management system, by improving the effacacy of using fixed capital, a model of internal audit of the fixed capital of enterprises has been proposed, which reflects organizational, legal, operational and financial control. Thus, organizational control provides control over the concentration and performance of functions of managing the elements of fixed capital in business units, as well as monitoring the availability of sources of information on machine and paper carriers for managing fixed capital. Legal control is exercised by monitoring compliance of the fixed capital management policy with laws and regulations, as well as monitoring compliance with the form and content of documents containing information on fixed capital, regulatory and legislative acts.

4. The enterprise economic security importance to ensure the enterprise effective management has been substantiated, its components have been determined: financial; intellectual and personnel; technical and technological; political and legal; informational; power; ecological. Also the main priority interests of the introduction of environmentally friendly technologies, which are the main capital for the enterprise, have been determinated.

Due to the lack of an effective capital management system in general at most domestic enterprises, in our opinion, the areas for further research are improvements in both capital management systems and types, which is one of the most pressing issues of economic transformations in modern conditions, as well as the research methods of this problem. Further research into the enterprise economic security aspects an in the effective management context includes various factors of its risk and the choice of the optimal management decision to eliminate economic threats and balance the enterprise economic security system, taking into account the scurrent unstable conditions for doing business and the need to find quick methods and decision-making methods to adapt needs of the market.

\section{References}

[1] A performance management framework for state and local government: From measurement and reporting to management and improving. Chicago: National Performance Management Commission. 2010.

[2]A. Alaoui, "Organizational Effacacy and X-Ineffacacy: Which Role of Learning Organization", Learning Models for Innovation in Organizations: Examining Roles of Knowledge Transfer and Human Resources Management. Hershey PA: IGI Global. 2013.

[3] V. Babenko, O. Nazarenko, I. Nazarenko, O. Mandych, „Aspects of program control over technological innovations with consideration of risks", Eastern-European Journal of Enterprise Technologies, Vol. 3/4 (93), pp. 6-14, 2018. DOI: https://doi.org/10.15587/1729-4061.2018.133603

[4] V. Babenko, N. Chebanova, N. Ryzhikova, S. Rudenko, N. Birchenko, "Research into the process of multi-level management of enterprise production activities with taking risks into consideration", Eastern- 
European Journal of Enterprise Technologies, vol. 1, No 3 (91), pp. 4-12, 2018. DOI: https://doi.org/10.15587/1729-4061.2018.123461

[5]I. Boyarko, Ya. Samusevich, "Theoretical aspects of the system of value-oriented enterprise management", Business Inform, vol. 9, pp. 282-284, 2012.

[6] O. Boyko, O. Katerinyuk, "The value of the management structure in the process of implementing an anticrisis strategy by the printing company", Economic sciences. Series: Economics and Management, vol. 8, pp. 38-44,. 2011.

[7]N. Chebanova, L. Revutskaya, N. Koroleva, "The role of information and analytical support of internal control in increasing the effacacy of enterprise management", Visnyk KhNUU. Series: Economic Sciences, vol. 3, pp. 77-86, 2017.

[8] Y. Chernysheva, G. Shepelenko, I. Gashenko, I. Orobinskaya, Y. Zima, "Business Analysis as an Important Component of Ensuring Enterprise's Economic Security", European Research Studies Journal, vol. XX, pp. 250-259, 2017.

[9] R. Coase, Company, the market and the right. New Publishing House, 2007.

[10] O. Deyneka, K. Russova A. Mihalko, "Theoretical approaches to enterprise management process", Zb. nauk. prats UGART, vol. 135, pp. 143-147, 2013.

[11] C. Didier, O. Danylenko, Yu. Shutyak, "The enterprise economic security concept in Ukrainian economic thoughts", ZN WSH Zarzadzani, vol. 4, pp. 27-45, 2015.

[12] P. Drucker, The Effective Executive. New York: HarperCollins, 2009.

[13] A. Goncharuk, Management of enterprise activity effacacy. Textbook. Astroprint, 2012.

[14] O. Gromova, O. Getman, T. Markova, Heat Pump Power Engineering in Environmentalizing the Fuel and Energy Complex in Ukraine: Perspectives of Development and Management Mechanisms: monograph: IREPR NAS, 2013.

[15] O. Gromova, T. Markova, "Theoretical-conceptual approaches to providing the mechanism of effacacy of heat pump power engineering", Economic innovation, vol. 48, pp. 116-124, 2012.

[16] A. Ianioglo, T. Polajeva, "Innovative enterprises economic security component: Moldova Republic case", Journal of Business Economics and Management, vol.18, pp. 1228-1242, 2017.

[17] W. Jeanne, P. Ross, David Robertson Enterprise Architecture. As Strategy: Creating a Foundation for Business Execution. A Harvard Business Review, 2006.

[18] O. Kalaman, "Analiz stanu ta osoblyvosti upravlinnia pidpryiemstvamy vynohradarsko-vynorobnoho pid kompleksu", Food industry Economics, vol. 4(7), pp. 40-44, 2015. DOI: 10.15673/2312-847x.4/2015.56740

[19] L. Kulakovska, Yu. PIcha, Organization and method of audit. Karavela, 2012.

[20] N. Lazareva, "The Methodical Approach to Evaluating the Modern Enterprise Effacacy", Scientific Herald of International Humanitarian University, Series: Economics and Management, vol. 8, pp. 103-109, 2015.

[21] F. Malerba, J. Nelson, Learning and Catching Up in Different Sectoral Systems: Evidence from Six Industries; Industrial and Corporate Change, 20 (6), 2011.

[22] N. Medzhybovskaya, "Formation of the information support system for increasing the effacacy of enterprise management", Economics: realities of time, vol. 4, pp. 26-30, 2013.

[23] G. Mintzberg, The Structuring of Organizations: A research Synthesis. Published by Lebanon, Indiana, U. S. A.: Prentice Hall, 2004.

[24] S. Onyshko, "Management of financial assets as a tool for ensuring the effacacy of the financial market", Scientific herald of the Chernihiv State Institute of Economics and Management. Series 1: Economics, vol. 2, pp. 105-110, 2014.

[25] P.P. Sengupta, M. Sinha, U.P. Dutta Economic and environmental performances in manufacturing industries: A comparative study Periodicals of Engineering and Natural Sciences Vol. 7, No. 1, pp. 99-108, 2019.

[26] O. Plahotnik, "Techno - technological component of the enterprise competitiveness system: assessment of the level and directions of improvement", ScienceRise, vol. 9 (1), pp. 13-18, 2015.

[27] A. Poddorogin, Ya. Nevmerzhitsky, "Effacacy of management of cash flows of the enterprise", Finance of Ukraine, vol. 11, pp. 119-127, 2007.

[28] M. Porter, E. Michael, Competitive advantage: How to achieve high results and ensure its sustainability per. from English. E. Kalinina. M.: Al'pina Biznes Buks, 2008.

[29] V. Ramon, Economic Security of Enterprise. 2017. 
[30] Sengupta P. P., Sinha M., Dutta U. P., Economic and environmental performances in manufacturing industries: A comparative study, Periodicals of Engineering and Natural Sciences, Vol. 7, No. 1, pp. 99-108, 2019.

[31] M. Shashina, V. Volodin, "Information component of enterprise economic security", Effective economy. $10,2016$.

[32] J. K. Shim, and J. G. Siegel, Enterprise Management. Economics for practitioners, M.: Filin, 2013.

[33] Yu. Sikanevych, "Use of internal cost of an enterprise as a general criterion of enterprise management", Responsible economy, vol. 4, pp. 212-215, 2012.

[34] T. Stupnitskaya, "The features of analysis of factors, influencing on a change profitability of the fixed assets", Economic innovation: Zb. nauk. prats, vol. 38, pp. 204-214, 2011.

[35] O. Sukhodolya, System analysis of public administration mechanisms in the field of energy effacacy. National Academy of Public Administration under the President of Ukraine. 2018.

[36] O.Tarkaniya, "Objects of control activity in the modern enterprise management system", Scientific works of MAUP, vol. 4, pp. 185-188, 2012.

[37] J. Van Horn, Fundamentals of financial management. Williams Publishing House, 2008.

[38] A. Vaschenko, "Effacacy of production and economic activity in the industrial enterprises management mechanism", EkonomIchniy vIsnik NatsIonalnogo gIrnichogo unIversitetu, vol. 1, pp. 80-87, 2014.

[39] E. Yeşilyurt, O. Şimşek, A. Bilgil, "Investigation of Availability of Raw Perlite in Refractory Building Material Production", Periodicals of Engineering and Natural Sciences, Vo. 6, No. 1, pp. 41-51, 2018.

[40] O. Zakharov, "Strategy of economic safety of the enterprise", Scientific herald of Lviv State University of Internal Affairs. Series economical, vol 2, pp. 272-282, 2012. 